\title{
How does regular exercise affect internet addiction level in university students? \\ Koçak Ç.V. ${ }^{\mathrm{ABCDE}}$
}

\author{
Faculty of Sport Sciences, Department of Physical Education and Sport Education, Hitit University, Çorum, Turkey
}

Authors' Contribution: A - Study design; B - Data collection; C - Statistical analysis; D - Manuscript Preparation; E-Funds Collection.

\begin{abstract}
Purpose: $\quad$ The internet is one of the most important technological developments of the era. Internet usage rate is increased rapidly. This intensity of use is thought to cause some behavior disorders in people. In this study, it was aimed to determine the internet addiction status of university students and to evaluate the relationship between regularly exercise and academic achievement.

Material: The study group is consisted $50[n=25$ female, $n=25$ male] university students. The mean of the age of participants was $21.47 \pm 1.66$ ] Data was collected by personal information form and Internet Addiction Test. SPSS 22 program was used in the analysis of the obtained data and Shapiro-Wilk Test was applied to determine whether the data showed normal distribution and the significance level was accepted as $p<0.05$ in the analyses. Data were normally distributed. Paired-Samples T-Test was used to analyze of the data.

Results: $\quad$ As the main hypothesis of the study, there was a significant difference between regularly exercise and internet addiction. Also, it was seen that the internet usage period of the participants who exercise regularly decreased.

Conclusions: Doing regular exercise can reduces the level of internet addiction and the time spent on the Internet. Regulating and reducing the time spent on the internet can help to protect from psycho-social, physical and physiological negative effects of Internet addiction. It may be suggested to do regular exercise for this. Measures should be taken to reduce and prevent internet addiction of university students. Research can be repeated with different variables in different samples. For example; researches about internet addiction in elite level athletes.

Keywords: university, student, internet, addiction, exercise.
\end{abstract}

\section{Introduction}

Addiction is evaluated as a psychiatric syndrome and the field is examined in two basic levels in the literature. These are addictions to chemicals and addictions on behavior. Both types of addictions adversely affect the organism's work. The physical and psychological symptoms come out such as to engage the mind, causing emotional lability, intolerance, interpersonal conflict and frequent relapse [1].

In these days, which we call the information age, the fastest and easiest access to information is undoubtedly through the internet. The emergence of the Internet has increased the possibilities of sharing information and facilitated the work of researchers. In addition to the use of the Internet as a means of accessing information; It is also used for many purposes such as communication, social relations, online gaming and series-watching. Along with the widespread use of the Internet, the negative effects on the individual and society have started to show itself. The main reason for these negative effects is the transformation of internet usage into addiction. Caplan [2] pointed out that overuse of the internet could adversely affect the biological, physiological, psychological and social development of the person.

The inability to prevent the use of internet and the resulting loss of ability is defined as internet addiction. Internet addiction is evaluated in behavioral addiction. One of the important findings in internet addiction; It is

(c) Koçak Ç.V., 2019

doi:10.15561/20755279.2019.0404 expressed as the time spent on the internet without meaning for the person. In addition to this, internet addiction can bring about problems such as showing tension and aggression, moving away from work, social and family life [3], also it can adversely affect to general health [4].

According to Young [5], internet addiction can bring another addiction. In a study conducted on young people, it was stated that internet addiction may cause attention deficit, hyperactivity disorder, social phobia and mild depression [6].

Exercise is considered a subclass of physical activity. Planned structured, voluntary, one or several elements of physical fitness are continuous activities aiming to develop [7-9]. Exercise is defined as planned and programmed movements that improve or maintain physical fitness parameters [10-12]. According to Koruç and Arsan [13] exercise has positive effects both physically and psychologically. People exercise to have fun, develop positive self and socialize [14]. It has also been stated in the studies that exercise protects psychological health by contributing to the reduction of anxiety and depression along with general health benefits [15]. It is important that the person feels good physically, psychologically and socially due to exercise. Öcal and Koçak [16] pointed out regular physical activity increases the students' school success.

Inactivity can bring great health problems. Immobility may occur due to various reasons. These reasons may not be time to exercise due to heavy working conditions. It may also be that the person has isolated himself/herself because of their dependencies [17]. Turkey Statistical 
Institute pointed out that Information Technology Usage Survey results in year 2018: 83.8\% of households in Turkey are using the internet. The age group with the highest rate of computer and internet use is 16-24 years old. According to the education level, the highest rate of internet use is $93.0 \%$ for college, faculty and above [18]. This statistical information brings to mind how the university students use internet habits.

The aim of the study is to seek an answer to the hypothesis that doing regular exercise reduces the internet addiction and time spent on the internet in university students. University students' internet addiction and doing regular exercise are not adequately explored in the relevant literature. The research is important in terms of contribution to the literature.

\section{Material and Methods}

\section{Model of the Research}

In this study, single group pretest posttest experimental design was used. Experimental design is the research to test the cause effect relationship between variables. In a single group pretest posttest experimental design, an independent variable is applied to a group, pre- and postexperiment is measured $[19,20]$. The difference between the pre-test and post-test averages indicates the effect of the independent variable on the dependent variable [21].

Participants:

The participants of the study consisted of 50 students $[n=25, n=25]$ who study in the faculties of theology, communication, engineering, health sciences and sport sciences in the academic year of 2018-2019. The mean age of the participants was 21.47 [ \pm 1.66$]$. The students sampled by convenience sampling method $[19,22]$. Convenience sampling is a frequently used sampling method in the field of sports sciences [23, 24]. The personal information of the participations is presented in Table 1.

According to Table 1, the mean age of the participants was $21.47[ \pm 1.66]$. The participants consisted of 25 female [50\%] and 25 male [50\%]. The majority of the participants were $24 \%$ in the Faculty of Sport Science and the second one is Faculty of Health Sciences $20 \%$.

Procedure:

Participants were university students who did not exercise regularly before deciding to join a fitness center. Participants reported that they performed physical activity for at least 3-5 days per week and at least 45 minutes per day. Internet addiction test was applied to the participants while registering to the fitness centers. At the end of 12 weeks, the Internet addiction test was applied again to the same participants who participated in the regular exercise in the fitness center.

\section{Data collection:}

Personal information such as gender, age, faculty, purpose of using internet was collected by the personal information form created by the researcher. Internet Addiction Test Short Form [İBT-KF] which was developed by Young [25] and adapted to Turkish by Kutlu, Savc1, Demir and Aysan [26] was used to determine the levels of internet dependency. The scale is a 5-point Likert-type self-assessment scale. It consists of 12 items and one dimension. The Cronbach Alpha overall internal consistency coefficient of the scale was 91. Data collection tools were applied face to face to the participants.

\section{Statistical Analysis:}

SPSS 22 program was used in the analysis of the obtained data and Shapiro-Wilk Test was applied to determine whether the data showed normal distribution and the significance level was accepted as $p<0.05$ in the analyses. Data were normally distributed. Paired-Samples T-Test was used to analyze the data.

\section{Results}

Shapiro-Wilk Test was applied to determine whether the data showed normal distribution and the significance level was accepted as $\mathrm{p}<0.05$ in the analyses.

According to Table 2, Skewness and Kurtosis values showed normal distribution. According to Tabachnick and

Table 1. The personal information of the participations

\begin{tabular}{lll}
\hline Gender & $\mathbf{f}$ & $\mathbf{\%}$ \\
\hline Male & 25 & 50.0 \\
Female & 25 & 50.0 \\
Total & 50 & 100.0 \\
Age & $f$ & $\%$ \\
$19-20-21$ & 25 & 50.0 \\
$22-23-24$ & 25 & 50.0 \\
Total & 50 & 100.0 \\
Faculty & $f$ & $\%$ \\
Theology & 10 & 20.0 \\
Communication & 9 & 18.0 \\
Engineering & 9 & 18.0 \\
Health sciences & 10 & 20.0 \\
Sports sciences & 12 & 24.0 \\
Total & 50 & 100.0 \\
\hline
\end{tabular}


Table 2. Normality test of data

\begin{tabular}{llllllll}
\hline Tests & $\mathbf{n}$ & Min. & Max. & sd & Mean & Skewness & Kurtosis \\
\hline Internet a pre test & 50 & 1.21 & 5.00 & .85747 & 3.3179 & .500 & -.141 \\
Internet addiction post test & 50 & 1.26 & 5.00 & .83446 & 2.6716 & -.518 & -.105 \\
\hline
\end{tabular}

Notes: $p<0.05$

Table 3. Evaluation of the internet addiction pre and post the participation of regular exercise

\begin{tabular}{lllllll}
\hline Tests & $\mathbf{n}$ & $\overline{\mathbf{x}}$ & $\mathbf{s d}$ & $\mathbf{d f}$ & $\mathbf{t}$ & $\mathbf{p}$ \\
\hline Internet addiction pre test & 50 & 3.3179 & .85747 & 49 & & \\
Internet addiction post test & 50 & 2.6716 & .83446 & 49 & -3.142 & $.003^{*}$ \\
\hline
\end{tabular}

Notes: $p<0.05$

Table 4. Evaluation of the internet usage time pre and post participation of regular exercise

\begin{tabular}{|c|c|c|c|c|c|c|}
\hline Tests & $\mathbf{n}$ & $\overline{\mathbf{x}}$ & sd & df & $\mathrm{t}$ & p \\
\hline Internet addiction pre test & 50 & 3.9000 & 1.03510 & 49 & \multirow{2}{*}{4.221} & \multirow{2}{*}{$.001^{*}$} \\
\hline Internet addiction post test & 50 & 3.1000 & .95298 & 49 & & \\
\hline
\end{tabular}

Fidell [27], Skewness and Kurtosis values between -1.5 and +1.5 indicate that the data is normally distributed.

Paired-Samples T-Test was used to determine the difference between the pre-test and post-test averages of internet addiction levels of the participants.

According to Table 3, there is a statistically significant difference between the participants' Internet addiction pre-test and post-test average $\left[\mathrm{t}_{[49]}=-3.142, \mathrm{p}=.003\right.$, $\mathrm{p}<.05]$. The post-test average of the participants $[\overline{\mathrm{x}}=$ 2.6716] was lower than the pre-test average $[\bar{x}=3.3179]$. Based on this finding, it can be said that doing regular exercise positively contributes to the reduction of students' internet addiction.

Paired-Samples T-Test was used to determine the difference between the pre-test and post-test averages of internet usage time of the participants.

According to Table 4, there was a statistically significant difference between the internet usage time pretest and post-test averages of the participants $\left[\mathrm{t}_{[49]}=4.221\right.$, $\mathrm{p}=.001, \mathrm{p}<.05]$. The final test average $[\overline{\mathrm{x}}=3.1000]$ of the participants was lower than the pre-test average $[\overline{\mathrm{x}}=$ 3.9000]. Based on this finding, it can be said that doing regular exercise positively contributes to the decrease in the time spent by students on the Internet.

\section{Discussion}

According to the findings of this study, there is a statistically significant difference between the participants' level of Internet addiction and their doing regular exercise. At the end of 12 weeks of regular exercise, it was determined that the level of internet addiction decreased. There are no literature findings on the effect of regular exercise on internet addiction. Therefore, it is difficult to compare the research findings with the literature.

Research reports indicate that internet addicts can experience psychosocial, physical and physiological negativity [28]. Young [29] stated that loneliness is among the reasons of internet addiction. In addition, those who spend time on the Internet for a long time still face problems such as back and back pain, vascular problems and obesity mentioned that there is a linear relationship between long-term use of internet and obesity and lack of physical activity [30].

Nowadays, the importance of active living in terms of individual and social health has become more understandable [31]. Physical activity has a positive effect on healthy development by ensuring the regular functioning of metabolic functions. It also helps prevent chronic diseases [32].

When the results of the research were evaluated, it was determined that doing regular exercise decreased the internet addiction and the level of time spent on the internet significantly. This may mean that students can reduce their leisure time and manage their routine more efficiently through regular exercise.

\section{Conclusion}

The obtained results support the hypothesis of the study. Regular exercise reduces the level of internet addiction and the time spent on the Internet. Reducing and regulating the time spent on the internet can help to protect the psycho-social, physical and physiological effects of Internet addiction. It may be suggested to do regular exercise for this. Measures should be taken to prevent university students from being addicted to the internet. Research can be repeated with different variables in different samples. For example; researches about internet addiction in elite level athletes.

\section{Conflict of interest}

There were no conflicts of interest. 


\section{References}

1. Griffiths MD. Internet addiction: an issue for clinical psychology? Clinical Psychology Forum. 1996; 97: 32-36.

2. Caplan SE. Problematic Internet use and psychosocial well-being: Development of a theory based cognitive-behavioral measurement instrument. Computers in Human Behavior. 2002; 18: 553-575. https://doi.org/10.1016/S0747-5632(02)00004-3

3. Young KS. What makes the Internet addictive: Potential explanations for pathological Internet use? In 105th annual conference of the American Psychological Association, 1997; 15:12-30.

4. KerbergCS.Problemandpathologicalgamblingamong college athletes. Annals of Clinical Psychiatry. 2005; 17(4): 243-247. https://doi.org/10.1080/10401230500295388

5. Young KS. Cognitive Behavior Therapy with Internet Addicts: Treatment Outcomes and Implications. CyberPsychology \& Behavior, 2007;10:671-9. https://doi.org/10.1089/cpb.2007.9971

6. Gönül AS. Patological internet use (internet dependency/ abuse). New Symposium. 2002; 40:105-110.

7. Şahin $\mathrm{O}$. The effect of regular exercise training on some physical and physiological parameters of children aged 1214. $\mathrm{PhD}$ [dissertation]. Selcuk University Institute of Health Sciences; 2007.

8. Bliznevsky A, Kudryavtsev M, Kuzmin V, Tolstopyatov I, Ionova $\mathrm{O}$, Yermakova $\mathrm{T}$. Influence of personal characteristics of pupils and students on the effectiveness of the relationship to the specific physical activities. Journal of Physical Education and Sport, 2016;16:424-32. https://doi.org/10.7752/jpes.2016.02066

9. Kamaev O, Proskurov E, Potop V, Nosko M, Yermakova T. Factors that influence somatic health of 10-11-year-old schoolchildren at the beginning and end of an academic year. Journal of Physical Education and Sport, 2017;17:407-13. https://doi.org/10.7752/jpes.2017.01060

10.Biddle SJH: European Perspectives on Exercise and Sport Psychology. UK: Human Kinetics; 1995.

11.Ivashchenko $\mathrm{O}$, Kapkan $\mathrm{O}$, Khudolii O, Yermakova $\mathrm{T}$. Informative Indicators of 14-15 Years' Age Boys' Motor Fitness. Teoriâ Ta Metodika Fìzičnogo Vihovannâ, 2017; 17(2): 86-97. https://doi.org/10.17309/tmfv.2017.2.1193

12.Lopatiev A, Ivashchenko O, Khudolii O, Pjanylo Y, Chernenko S, Yermakova T. Systemic approach and mathematical modeling in physical education and sports. Journal of Physical Education and Sport, 2017;17:146-55. https://doi.org/10.7752/jpes.2017.s1023

13.Koruç Z, Arsan N. Determinants of exercise behavior: exercise adherence and exercise dependence. Turkish Journal of Sport Medicine. 2009;44:105-113.

14.Willis JD, Campbell FL. Exercise Psychology. USA: Human Kinetics; 1991.

15.Koruç Z, Bayar P. The role and effects of exercise in the treatment of depression. Hacettepe Journal of Sport Sciences. 2004;1: 49-64.

16.Öcal K, Koçak SM. The effect of school sports on the academic achievement and behavioral development of secondary school students. Mediterranean Journal of Educational Research. 2010; (7): 89-94.

17.Anderson CA, Bushman BJ. Effects of violent video games on aggressive behaviour, aggressive cognition, aggressive affect, physiological arousal, and prosocial behaviour: A meta-analysis of the scientific literature. Psychosocial Science. 2001;12: 353-359. https://doi.org/10.1111/1467-9280.00366

18.Türkiye İstatistik Kurumu [Turkish Statistical Institute]. The Information of Technology Usage Survey in 2018 [document on the Internet]. 2019 Jan 21 [cited 2019 Feb 13]. Available from: http://www.tuik.gov.tr/PreTablo.do?alt_id=1028

19.Cohen LM, Manion LL. Research Methods in Education. New York: Routledge; 1998.

20.Fraenkel JR, Wallen NE. How to design and evaluate research in education [6th ed. ]. New York: McGraw-Hill International Edition; 2006.

21.Gay LR, Airasian P. Educational research: Competencies for analysis andapplication. Upper Saddle River, NJ: Merrill Prentice Hall; 2000.

22.Büyüköztürk Ş, Kilıç Çakmak E, Erkan Akgün Ö, Karadeniz Ş, Demirel F. Bilimsel araştırma yöntemleri [Scientific research methods]. 23rd ed. Ankara:Pegem Akademi Yayıncılık; 2017. (In Turkish) https://doi.org/10.14527/9789944919289

23.Koçak F. The relationship between leisure constraints, constraint negotiation strategies and facilitators with recreational sport activity participation of college students. College Student Journal. 2017; 51(4): 491-497.

24.Koçak F. Leisure constraints and faciltators: Perspectives from Turkey. European Journal of Physical Education and Sport Science. 2017; 3(10): 32-47. https://doi.org/10.5281/zenodo.852540

25.Young KS. Psychology of Computer Use: XL. Addictive Use of the Internet: A Case That Breaks the Stereotype. Psychological Reports, 1996;79:899-902. https://doi.org/10.2466/pr0.1996.79.3.899

26.Kutlu M, Savc1 M, Demir Y, Aysan F. Turkish adaptation of Young's Internet Addiction Test-Short Form: a reliability and validity study on university students and adolescents. Anatolian Journal of Psychiatry. 2016;17:69-76. https://doi.org/10.5455/apd.190501

27.Tabachnick BG. And Fidell LS. Using multivariate statistics. Boston, Pearson; 2013.

28.Tsai CC, Lin SSJ. Internet addiction of Taiwanese adolescents: an in-depth interview study. In 107th annual convention of the American Psychological Association, Washington: DC; 2000.

29. Young KS. Internet addiction: symptoms, evaluation and treatment. Innovations in clinical practice: A source book. 1999; 17(17): 351-352.

30.Shields MK, Behrman RE. Children and computer technology: Analysis and recommendations. The Future of Children. 2000; 4-30. https://doi.org/10.2307/1602687

31.Mackinnon LT, Ritchie CB, Hooper SL, Abernethy PJ. Exercise Management: Concepts and Professional Practice. Champaign, Ill: Human Kinetics; 2003.

32. Chakravarthy MV, Booth FW. Eating, exercise, and "thrifty" genotypes: connecting the dots toward an evolutionary understanding of modern chronic diseases. Journal of Applied Physiology, 2004;96:3-10. https://doi.org/10.1152/japplphysiol.00757.2003 


\section{Information about the author:}

Koçak Ç.V.; http://orcid.org/0000-0002-1403-0812; velikocak@hitit.edu.tr; Faculty of Sport Sciences, Department of Physical Education and Sport Education, Hitit University; North Campus, Ring Road, 19030, Corum, Turkey.

\section{Cite this article as:}

Koçak ÇV. How does regular exercise affect internet addiction level in university students? Physical education of students, 2019;23(4):186-190.

https://doi.org/10.15561/20755279.2019.0404

This is an Open Access article distributed under the terms of the Creative Commons Attribution License, which permits unrestricted use, distribution, and reproduction in any medium, provided the original work is properly cited http://creativecommons.org/licenses/by/4.0/deed.en

Received: 29.05.2019

Accepted: 30.06.2019; Published: 28.08.2019 